\title{
Featherwing Beetles (Insecta: Coleoptera: Ptiliidae) ${ }^{1}$
}

Henry S. Dybas ${ }^{2}$

\section{Introduction}

Featherwing beetles are the smallest known beetles, the majority of the species being a millimeter or less in length. The common name is derived from the distinctive structure of the wings which are believed to function primarily for passive flotation, as in the ciliate seeds of dandelions. These wings are normally folded out of sight under the wing covers or elytra, which in some genera are shortened and truncate. However, in preserved specimens the featherwings often project beyond the apex of the elytra and aid (together with the minute body size) in the recognition of this family.

The family Ptiliidae is widely distributed in temperate and tropical regions of the world. About 23 genera and 115 species are listed from the United States, but many more remain to be described and named. The beetles are very abundant in Florida and neighboring areas but are rarely seen by most entomologists because of their minute size and cryptic habits. Featherwing beetles are not destructive but are especially interesting from an ecological and evolutionary standpoint because of their special

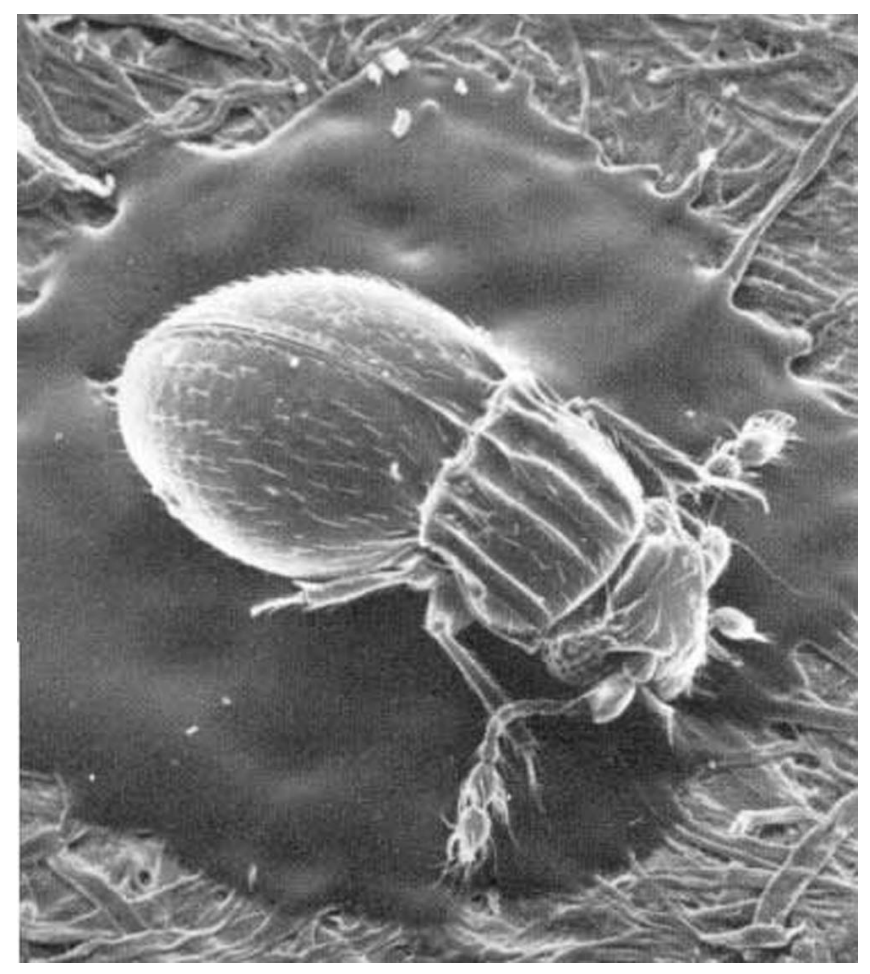

Figure 1. Undescribed species of featherwing beetle (Ptiliidae), less than $1 \mathrm{~mm}$ long. Credits: Division of Plant Industry

adaptations to life at the extreme lower limits of size in the order Coleoptera.

1. This document is EENY-177 (originally published as DPI Entomology Circular 218), one of the Featured Creatures series of the Entomology and Nematology Department, Cooperative Extension Service, Institute of Food and Agricultural Sciences, University of Florida. Published: November 2000. This document is also available on Featured Creatures Website at http://creatures.ifas.ufl.edu. Please visit the EDIS Website at http://edis.ifas.ufl.edu Additional information on these organisms, including many color photographs, is available at the Entomology and Nematology Department website at http://entnemdept.ifas.ufl.edu/.

2. Henry S. Dybas, curator, Division of Insects, Field Museum of Natural History, Chicago, IL.

The Institute of Food and Agricultural Sciences (IFAS) is an Equal Employment Opportunity - Affirmative Action Employer authorized to provide research, educational information and other services only to individuals and institutions that function without regard to race, creed, color, religion, age, disability, sex, sexual orientation, marital status, national origin, political opinions or affiliations. For information on obtaining other extension publications, contact your county Cooperative Extension Service office. Florida Cooperative Extension Service / Institute of Food and Agricultural Sciences / University of Florida / Larry R. Arrington, Interim Dean 


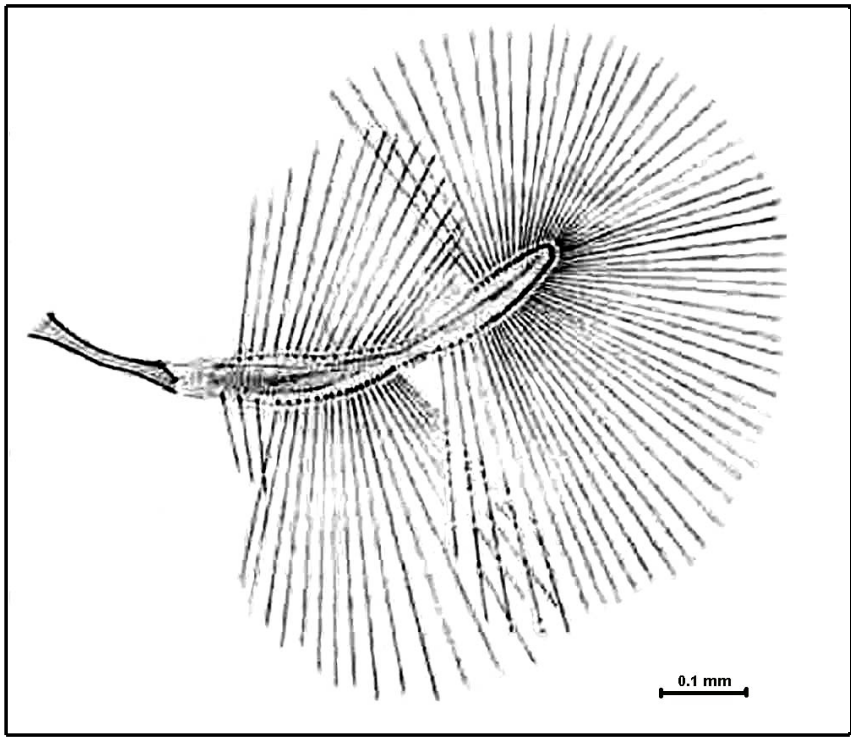

Figure 2. Extended featherwing (ca. $1 \mathrm{~mm}$ long) of Bambara testacea (Britt.), a featherwing beetle of Florida. This is a parthenogenetic species less than $1 \mathrm{~mm}$ long that is widely distributed in the tropics and subtropics of both hemispheres. Credits: Division of Plant Industry

\section{Natural History}

Featherwing beetles live in habitats such as leaf-litter on the ground, decaying logs, compost heaps, treeholes, decaying fungi, animal dung, under bark, sea weed on sea shores, and in other moist organic materials suitable for growth of the molds and fungi upon which the larvae and adults feed. Recently in Florida, featherwing beetles have been found in numbers in an old alligator nest, a kind of natural compost heap that has presumably been an available habitat for featherwing beetles for some millions of years. The most minute members of the family -- and thus the world's smallest beetles -- belong to the genus Nanosella and its allies, which live in the spore tubes on the underside of shelf fungi (Polyporaceae). The smallest member of this group is an undescribed South American species that is only $0.35 \mathrm{~mm}$ long, not much larger than a single-celled Paramecium, yet it has compound eyes, antennae, complex mouthparts, wings, and all the other essential structures of its larger relatives, a complex organization packed into a remarkably small space. Several related species, almost as small, are common in Florida but are not named and described yet. The beetles can be seen, with a 10X hand lens, popping in and out of the spore tubes of fresh polypore fungi and crossing the under surface for short distances.

\section{Life Cycle}

Under favorable conditions Ptiliidae appear to reproduce continuously; larvae often are found together with both teneral and fully hardened adults at different times of the year. Only a single egg is accommodated and matured in the abdomen at a time, and this egg is nearly half the female body length (Dybas 1978). The developmental period seems to be short; mean time from egg to adult in three British species of Ptinella was 32 to 45 days at 20 degrees C, with three larval instars (Taylor 1975). Larvae are pale, slender, and active (Dybas 1976). The pupal stage has been described adequately only for Acrotrichis fascicularis (Hinton 1941).

\section{Collecting Procedures}

The most effective means of collecting Ptiliidae is by using the Berlese or insect funnel. Decaying moist organic detritus is placed on a screen in the funnel and subjected to gentle heat and drying (most commonly from an electric light bulb). The featherwing beetles and other arthropods gradually work their way down through the screen and accumulate in a jar of preservative at the apex of the funnel. The use of this apparatus permits systematic sampling of microhabitats in an area and accumulation of adequate series for study. Other collecting methods are hand-picking in the field (for example under bark), sifting debris with a hand screen over a white sheet, or waving a fine-mesh "aerial-plankton" net in the late afternoon when featherwing beetles are frequently found flying or floating in the air. They are found often in soil samples collected for nematode sampling.

\section{Polymorphism}

Many species of featherwing beetles are characterized by a striking polymorphism, in which each sex is represented by two different forms:

1. a normal morph with well-developed eyes, wings, and body pigmentation; and

2. a vestigial morph in which eyes, wings, and body pigmentation are reduced or lacking. 
The vestigial morph is always the most abundant form, comprising $90 \%$ or more of all the individuals. The two forms are so different that they appear to be different species or genera. Polymorphism of this kind occurs in several genera in Florida (i.e., Ptinella, Pteryx, and Ptinellodes (Dybas 1978)).

\section{Parthenogensis}

Ptiliidae have an unusually high incidence of thelytokous parthenogenesis (the production of females from unfertilized eggs). In Florida, five of seven species in the pantropical genus Bambara are known from females only (Dybas 1966; recorded under the name Eurygyne).

\section{Current State of Knowledge}

The family Ptiliidae is one of the least known groups in the Coleoptera. Few North American species can be identified correctly from the literature, and many species (judging by existing collections) still remain to be described and named. The beetles are studied best on microscope slides, where many useful characters of the underside can be seen and illustrated. Among the most useful structures for separating closely related species is the sperm storage organ (spermatheca) of the female which exhibits diagnostic differences in form in almost every species.

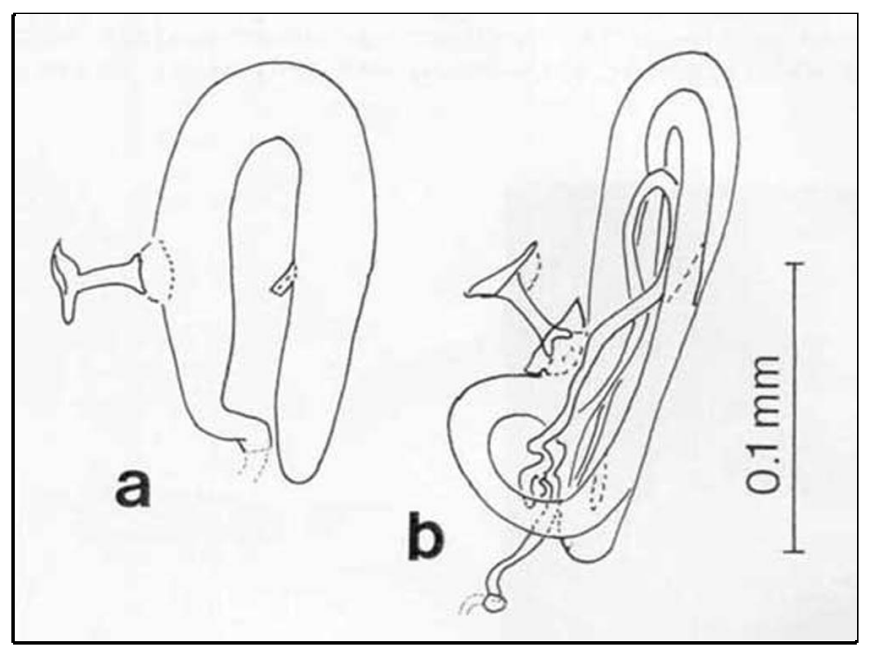

Figure 3. The sperm storage organs (spermatheca) of the female, a) Bambara testacea (Britt.), Florida; b) Bambara wagneri (Dybas), Florida. Species-specific differences in the form of the spermatheca are the rule in ambrosia beetles (Ptiliidae). Credits: Division of Plant Industry

\section{Selected References}

Dybas, H.S. 1966. Evidence for parthenogenesis in the featherwing beetles, with a taxonomic review of a new genus and eight new species (Coleoptera: Ptiliidae). Fieldiana, Zool. 51: 1152.

Dybas, H.S. 1976. The larval characters of featherwing and limulodid beetles and their family relationships in the Staphylinoidea (Coleoptera: Ptiliidae and Limulodidae). Fieldiana, Zool. 70: 2973.

Hinton, H.E. 1941. The immature stages of Acrotrichis fascicularis (Herbst) (Col. Ptiliidae). Ent. Monthly Mag. 77: 245-250.

Taylor, V.A. 1975. The biology of featherwinged beetles of the genus Ptinella with particular reference to co-existense and parthenogenesis. PhD. Thesis, Univ. London; 296 p. 